\title{
Humboldt's woolly monkeys decimated by hunting in Amazonia
}

\author{
Carlos A. Peres
}

\begin{abstract}
Humboldt's woolly monkeys Lagothrix lagotricha have been systematically hunted, mostly for food, to the point of becoming locally extinct wherever humans share their habitat. Remaining populations in the extensive lowland Amazonian range of this species are restricted to remote, unflooded terra firme forests. These populations are, however, quickly wiped out once access is opened by new roads. Terra firme forests, even in entirely undisturbed sites, are seasonally far less productive and can only sustain relatively low population densities. Woolly monkeys are currently more susceptible to hunting than perhaps any other vertebrate in the New World tropics and, as such, should be regarded as highly endangered.
\end{abstract}

Barrigudos (literally, 'pot-bellies'), as woolly monkeys are known in Brazil, have been hunted by native Amerindians in the Amazon for millennia. Although Friar Gaspar de Carvajal in 1542 had already reported that Amazonian monkeys were hunted for food (Medina, 1934), Bates (1863) was the first to document that 'the Barrigudo is much persecuted by the indians, on account of the excellence of its flesh as food. The species is very numerous in the forests of the higher lands, but owing to long persecution, it is now seldom seen in the neighbourhood of the larger villages. Owing to these traits (mild and confiding temper) the Barrigudo is much sought after for pets'. In addition, Bates 'calculated that one horde of the Tucuna indian tribe, near Tabating, 200 in number, destroyed 1200 of these monkeys annually for food'.

Today woolly monkeys are still preferred hunting targets, highly vulnerable to even moderate levels of human predation, and severely threatened in any area occupied by indians and non-tribal Amazonian inhabitants, or caboclos. Despite the woolly monkeys' ability to survive near the fringes of small, mobile human settlements until recently, the hunting threat they face, as pointed out by Bates, has been severely aggravated. Meanwhile, conservationists have remained largely oblivious to the tragic impact of humans on the present status and distribution of woolly monkeys.

Here I present evidence from surveys I have conducted on western Amazonian primate communities (Peres, 1990), which include woolly monkeys, in both hunted and nonhunted sites to show that humans have drastically decimated woolly monkey populations and in most cases driven them to local extinction. This evidence is then combined with that from a year-round study of an unhunted population of woolly monkeys Lagothrix lagotricha cana in the upper Urucu river $\left(4^{\circ} 27^{\prime} 55^{\prime \prime} S\right.$, $65^{\circ} 26^{\prime} 53^{\prime \prime} \mathrm{W}$ ), Amazonas, Brazil (Figure 1), to assess why they are currently the most vulnerable South American primates to threats other than habitat destruction. Their present occurrence at this site stands at odds with accessible sites elsewhere in the species's range where subsistence or commercial hunting has never been controlled.

\section{Distribution and ecology}

There are two recognized species of Lagothrix (Fooden, 1963): the yellow-tailed L. flavicauda, and Humboldt's woolly monkeys L. lagotricha. The former occurs in small pockets of montane cloud forest, from 1700 to $2700 \mathrm{~m}$, in northern Peru; the latter, consisting of four subspecies, 
throughout central-western Amazonia, west of the Negro and Tapajós rivers to the eastern slopes of the Andes (Figure 1). Together they comprise one of the least known, and most interesting, New World primate genera. Woolly monkeys are among the largest bodied arboreal animals in tropical America. Adults weigh over $8.5 \mathrm{~kg}$ and up to $12 \mathrm{~kg}$, almost always heavier than those of other monkey species sharing any given forest community. Spider monkeys Ateles spp. rival them in size, but their density is usually inversely correlated with that of Lagothrix at any one site, if they cooccur at all, as a function of differential habitat use. Both genera play key ecological roles, often dispersing seeds too large to be ingested intact by smaller vertebrates. Woolly monkeys, however, have a far more widespread use of Amazonian unflooded forests, usually far removed into remote interfluvial areas. They also live in much larger and more cohesive groups, and reach a greater group biomass than that of any other Neotropical primate. My study group of 39-41 independently locomot-

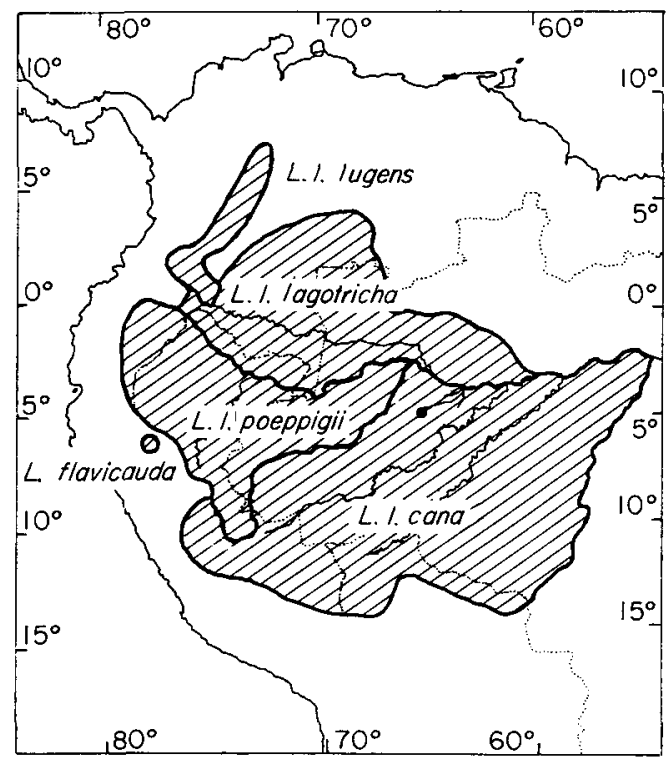

Figure 1. Geographic distribution of woolly monkeys (Lagothrix) in central-western Amazonia. Thick lines represent sub-specific range boundaries for $L$. lagotricha, as postulated by Fooden (1963). Changes in pelage morphs are in fact gradual and a new taxonomic revision is recommended. Location of the upper Urucu study site is shown by a solid dot. ing individuals weighed an estimated 279-286 $\mathrm{kg}$ in total. These factors, combined with a low group density, create a very clustered distribution of Lagothrix biomass. They subsist yearround largely on ripe fruit pulp, although exudates of Parkia pods, immature seeds, flowers, and young leaves are also important in their diet, particularly in the dry season. Groups in the upper Urucu behave as large, uncohesive, single spatial units using an area as large as $1300 \mathrm{ha}$, one of the largest home ranges documented for any Neotropical primate. The only other systematic study of Lagothrix, in a more productive and less seasonal south-eastern Colombian site, revealed a home range of 749 ha (Defler, 1989, pers. comm.). Woolly monkeys are vulnerable to even the subtlest anthropogenic habitat disturbance. They shy away from even small, man-made, 2-ha clearings, and hesitate approaching dirt roads within $500 \mathrm{~m}$, yet their day-to-day quest for food requires long-distance movements, to the point of becoming seasonal vagrants. Thus roads become intraversable barriers to such movements.

\section{Susceptibility to hunting}

Body mass alone largely determines the choice of game hunted in Amazonian forests, effectively explaining most of the difference in primate densities and biomass between hunted and unhunted sites (Peres, 1990). Woolly monkeys are preferred game primarily because of their large body mass. They also make delightful pets, fetching up to \$US80 locally. Young woolly monkeys, which are often found for sale in small Amazonian towns, and even in Manaus, are invariably captured after the mother has been shot down. In addition, because of the woolly monkeys' highly clustered distribution, a hunter can harvest a large proportion of a local population in a single hunting foray. For instance, reliable reports of as many as 12 Lagothrix from a single group being killed during a two-man hunt are not uncommon in remote sites accessible only in the wet season via perennial streams. During a 1987 survey of a terra firme site near Lago da 


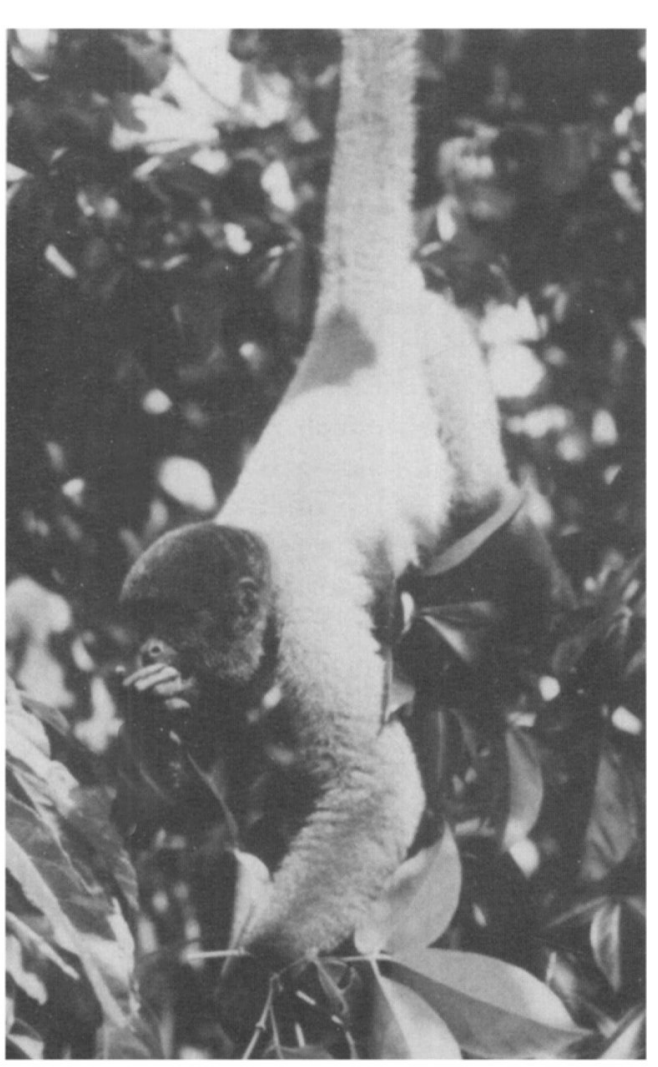

Sub-adult female Lagothrix lagotricha cana feeding on fruits in the canopy of a non-hunted terra firme site.

Fortuna, an oxbow lake off the Juruá river, I saw two rubber-tappers carrying a fresh kill of five adults and one juvenile to the palmthatched huts they had built for that wet season. Subsistence and commercial hunting of $L$. lagotricha elsewhere in the Amazon has been documented by a number of biologists and anthropologists. The species accounted for 62 per cent of 1507 monkeys found for sale in the meat market of Iquitos, Peru (Castro et al., 1976). In a study of a group of 230 Waorani indians in Ecuador, Youst and Kelly (1983) recorded 562 L. lagotricha kills over a 275-day period, representing the numerically most important game-species harvested by this tribe.

Considering the approximate size of their hunting range, I calculate that the Waoranis harvested an average of 0.34 Lagothrix per sq $\mathrm{km}$ per year. Given my non-hunted popula- tion density in the upper Urucu river (Table 1), and that the number of infants produced by one group during one year represented 12.5 per cent of its size, I estimate that at my site the Waorani harvest would represent 23 per cent of the population's reproductive rate. Such a crude assessment of hunting-induced mortality is certainly an underestimate for a number of reasons.

First, the number of monkeys killed by hunters anywhere far exceeds those which reach the pot, particularly if non-traditional weapons are used. This is the case in most of the current Lagothrix range used by man, where hunters with shotguns have mostly replaced, or displaced, those with blowguns and bow-and-arrows. Given the greater range and pattern size of shotgun projectiles, they are far more efficient at hitting a target animal as well as injuring its nearest neighbours. However, the fact that prehensile-tailed monkeys, such as Lagothrix, rarely lose their grip, remaining attached to branches after being shot, makes them difficult to retrieve. Yet they are large enough to be worth several shots at a group before one or a few animals drop to the ground. This results in many fatally-wounded animals escaping the hunter, but subsequently dying within a few days.

Secondly, my preliminary data from the Urucu population suggest that reproductive output of Lagothrix is indeed very low. Although weaning of infants in captivity takes some 24 months (Williams, 1967; Mack and Kafka, 1978), interbirth intervals seem to be considerably longer in the wild, roughly 3 years (Peres, unpubl. data). Symington (1987) also estimates that female black spider monkeys Ateles paniscus chamek, a closely related Atelinae, can only produce four to five offspring during a lifetime reproductive effort of 20 years. Field evidence is again supported by data from the longest-term captive colonies of Ateles and Lagothrix, which indicate that a breeding female can wean at most five young in its entire life span. Should this be the case with woolly monkeys in the Urucu, birth rate would be even lower at 0.96 infants per sq $\mathrm{km}$ per year, constituting roughly one-third of the total Waorani harvest. Hunting itself also 
depresses population density resulting in an indirect decline of a population birth rate per unit area.

Thirdly, given the choice of different age and sex of group-members, mortality is often biased towards lactating females. This is because the infants they carry give hunters an additional bonus in the few cases they can be successfully retrieved and kept alive until sold. Based on interviews with hunters in western Brazilian Amazonia, I estimate that on average at least 10 females have been sacrificed for every infant surviving to the nearest town. Because infant mortality is high in pet woollies (they are vulnerable to a range of diseases common to humans), this ratio is even higher for weaned juveniles reaching larger markets. Breeding females also tend to be easier targets, fleeing more slowly than other members of the group. These factors result in a male-biased sex-ratio, which should be inversely covariant with population reproductive rate, which in turn depends largely on the number of reproductive females.

Woolly monkeys are now often 'missing' in areas where they should be present on the basis of previous collecting records. As viable populations become more accessible, hunters wipe them out in the course of a few years, leaving no traces for collectors and field primatologists. The evidence that woolly populations are profoundly affected by hunting is thus twofold. First, they are absent, or extremely rare and aware of humans wherever they have been hunted in the past (e.g. Mittermeier, 1987), and second, a dramatic population recovery may occur where they have been released from illegal poaching and subsistence hunting (e.g. Cahuana Island, Pacaya-Samiria National Reserve, Peru: Soini, 1986). Because of their preference for undisturbed forest, and their relatively low reproductive rate, woollies are often locally extinct in areas where 3 or more years of consistent selective hunting has taken place (Peres, unpubl. data). Local rubber tappers along the main white-water tributaries of the Amazon, such as the Juruá and Purús rivers, admit that woolly monkeys have 'moved away' because they are intolerant of hunting. Elsewhere in
Amazonia they, as well as other large monkeys, are also shot by fur-hunters to lure jaguars and ocelots. Woolly monkeys are more vulnerable to hunters during the fruiting season. This is because whole groups may coalesce to form larger bands; they become considerably more cohesive than in the dry season and their body mass increases considerably, primarily from fat storage. They consequently become easier prey because hunters can shoot several animals in a single hunt, and heavier animals tend to travel lower in the canopy and flee from hunters less efficiently. Greater hunting effort is also allocated to 'fat monkeys' for both nutritional and medicinal reasons (Lagothrix fat is thought to aid healing various illnesses in many parts of their range). Caboclos near small tributaries of the Juruá river deliberately coincide their upstream hunts with the time of superabundant ripe fruit crops used by $L$. lagotricha, such as Theobroma subincanum (Sterculiaceae) and Couma macrocarpa (Apocynaceae). Monkeys at this time are said to become easier targets, probably because groups are more conspicuous and cohesive. According to Youst and Kelly (1982) the Waorani also kill a significantly larger number of woolly monkeys during the fruiting peak, or 'fat season', and will expend considerable effort to do so. Yet there is no evidence of either caboclos or indians sparing reproductive females, even though most births occur at this time of year.

\section{Recent surveys}

A number of short-term surveys and field studies indicate that the impact of human predation on woolly monkeys is severe. Accessible sites, near roads or rivers, hold few woollies or none at all (Table 1). L. lagotricha had been driven locally extinct in all hunted sites I surveyed, even though human habitat disturbance had never taken place in them. In contrast, the species accounted for most of the primate biomass in sites that had never been subject to hunting. Elsewhere, only two groups of Lagothrix were sighted in $242 \mathrm{~km}$ covered in seven Peruvian hunted sites where 
they were undoubtedly known to occur previously (Freese et al., 1982). At the eastern extremity of their range, 35 Lagothrix were killed in 4 months by a group of Brazilian colonists settled in Dardanelos, Mato Grosso. They were then the third most important mammalian game taken (Ayres et al., 1990). Two years later woolly monkeys had dropped out entirely from a subsequent list of animals hunted, presumably because they could no longer be found. In hunted sites, however, small-bodied primates fare considerably better than woollies, suffering little, if any, decline when compared with unhunted sites. For example, an isolated community of three rubber tappers, hunting to feed their extended families at a site on a tributary of the Jutaí river, killed a minimum of 200 woolly monkeys, 100 spider monkeys, and 80 howlers between early 1985 and late 1986. Smaller monkeys were occasionally shot, but still remained in viable densities. During a late1988 survey at this site, I found small and medium-sized monkeys to be common, but woollies were locally extinct, spider monkeys nearly extinct, and howlers drastically reduced. On the other hand, unhunted, remote terra firme sites, such as the upper Urucu, accessible only by helicopters, safeguard comparatively high-density Lagothrix populations despite the generally very low levels and strong seasonality of fruit production (Peres, unpubl. data).

\section{The Couma connection}

One widely-practised extractive activity interacting heavily with remaining Lagothrix populations is that of rubber tapping. The more sedentary lifestyle led by tappers of Hevea trees (Euphorbiaceae) currently plays a minor impact on woolly monkeys, because woollies no longer thrive in high-density Hevea habitats: they have been simply hunted out and driven locally extinct. The booming rubber trade in Amazonia, almost a century ago, paved the way to unsustainable hunting pressure on large primates such as Lagothrix. The pace of this process was dictated by factors

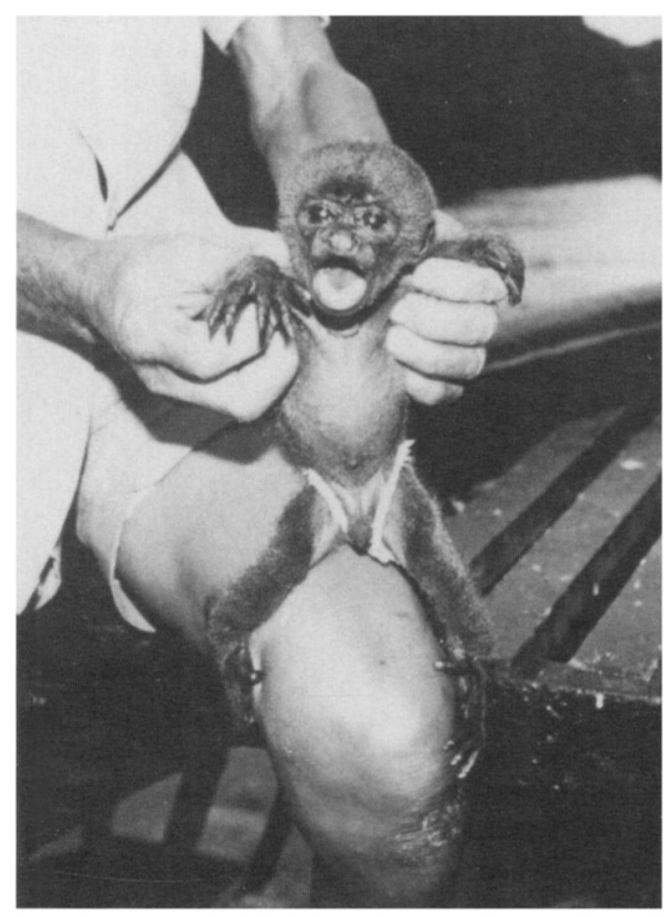

Unweaned infant Lagothrix lagotricha cana captured after its mother was killed by a hunter. As in most cases, it died a few days later.

such as local availability of alternative sources of protein and cultural exchange with indians inhabiting the same areas. In many western Amazonian areas near large, meandering rivers, the seasonal harvest of fish fluctuates markedly with the water level. Fish tend to abandon oxbow lakes and disperse widely in flooded forests for at least 4 months of the year, when settlers may shift to alternative sources of latex where they can subsist on forest wildlife including large primates and ungulates.

One such alternative is Couma macrocarpa, a focus of recent interactions between rubbertappers and woollies. Couma trees are widely distributed away from large rivers, where human settlements are sparse to absent. Even then, woolly numbers have declined in many areas, apparently as a consequence of seasonal incursions of large parties of Couma tappers. Couma trees are ringed precisely when their ripe fruit crops are used by Lagothrix, thus making them a point of convergence for both hunters and prey, clearly to the detriment of 
Table 1. Estimates of population density and biomass of woolly monkeys and other primate species in hunted and unhunted sites in central-western Amazonian sites where L. lagotricha was known to occur. The species was considered locally extinct $(t)$ if it was not detected during the survey, and had not been sighted by hunters for at least 2 years

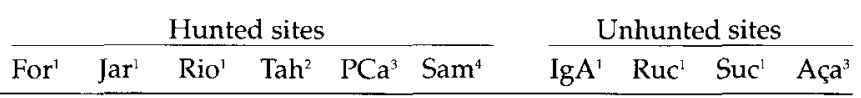

\section{Woolly monkeys}

Population density (no./sq km)

Crude biomass ( $\mathrm{kg} / \mathrm{sq} \mathrm{km}$ )

All other diurnal primates

Combined density (no./sq km)

Crude biomass $(\mathrm{kg} / \mathrm{sq} \mathrm{km}$ )

Total number of primate

species known to occur

Distance surveyed $(\mathrm{km})$

$\begin{array}{rrrrrrrrrr}\boldsymbol{t} & \boldsymbol{t} & \boldsymbol{\dagger} & 1 & 6 & 7 & 30 & 27 & 20 & 17 \\ \boldsymbol{+} & \boldsymbol{\dagger} & \boldsymbol{\dagger} & 10 & 48 & 56 & 244 & 223 & 160 & 136 \\ & & & & & & & & & \\ 202 & 106 & 253 & 81 & 150 & 154 & 81 & 134 & 50 & 50 \\ 356 & 120 & 404 & 102 & 175 & 341 & 177 & 265 & 86 & 147\end{array}$
14

$56 \quad 50$

$\begin{array}{llll}12 & 14 & 12 & 12\end{array}$

50

$\begin{array}{rrr}4 & 12 \\ 4 & 120 & 5\end{array}$

Survey sites: For=Lago da Fortuna, Juruá river, Brazil; Jar=Jaraquí river, Brazil; Rio=Riozinho river, Brazil; Tah=Tahuayo, Peru; PCa=Ponta da Castanha, Tefé river, Brazil; Sam=Samiria river, Peru; IgA= Igarapé Açú, lower Urucu river, Brazil; Ruc=upper Urucu river, Brazil; Suc= upper Tefé river, Brazil; Aça-Açaituba, Tefé river, Brazil.

Sources: (1) Peres, 1987, 1990; (2) Bodmer et al., in press; (3) Johns, 1986; (4) Freese et al., 1982.

the latter. In addition, survivorship of ringed trees is very low, which greatly depresses the local availability of this important source of fruits for residual woollies.

\section{Conservation status}

L. lagotricha has been listed as 'Vulnerable' in The IUCN Mammal Red Data Book (Thornback and Jenkins, 1982). In line with IUCN definitions, however, all forms of woolly monkeys should be regarded as 'Endangered' because they will continue to be rapidly driven to extinction in areas accessible to humans by factors that, given present circumstances, will remain operative. The status of woolly monkeys in Brazil has been recently upgraded to 'Endangered' following suggestions I made to members of a committee reviewing IBAMA's (Brazilian Environmental Institute) list of animals threatened with extinction.

A total of 11 conservation units comprising
$51,612 \mathrm{sq} \mathrm{km}$ are reported to contain woolly monkeys, mostly $L$. l. cana, in Brazil, only one of which safeguards a population of L. l. poeppigii (Rylands, 1985). While this may seem a satisfactory figure, it roughly equates to the average area of primary forest burnt in Brazilian Amazonia in each of the last 3 years (N. Myers, pers. comm.). Additional reserves for the two subspecies south of the mainstream Solimões-Amazonas should be considered along the Purús and Juruá rivers, between the headwaters of these two rivers in Acre, and along the Tefé river. It remains unclear whether protein-hungry rubber-tapper communities will be able to co-exist with viable numbers of sensitive game species in their so-called 'extractive reserves'. Conservation units may prevent forest disturbance, but in practice do less to protect these species because their primary threat-hunting - is not discouraged by land status, but by lack of access. Enforcing a ban on Lagothrix hunting would be a formidable task, but trade could be effectively 
discouraged if pet monkeys were confiscated by the already present IBAMA's outposts in small towns in Brazilian Amazonia. Between 1962 and 1972, 29,500 pet woollies were exported from Colombia and Peru (Green, 1976; Soini, 1972). Since then, tougher international restrictions, even in those countries, have done little to effectively stamp out trade of wild-born infants because this is a by-product of harvest of adults, valued a priori as a source of meat.

Woolly monkeys make at best a 'bad' game species for subsistence or commercial hunting, not because they contribute to the ephemeral wild-meat bonanza made possible when new forest sites become accessible, but because they are soon eliminated from the list of a more sustainable menu.

\section{Acknowledgments}

My field study would not have been possible without a World Wildlife Fund-US grant administered by R. A. Mittermeier and R. Mast. I thank the Brazilian oil company, Petrobrás, and G. G. Siegl for facilitating my access to sites in the Urucu, Tefé, and Juruá rivers. J. Y. Robertson, R. Beckwith, D. J. Chivers, and R. A. Mittermeier kindly offered comments on the manuscript. My studies in Cambridge are funded by the Brazilian Science Council, CNPq.

\section{References}

Ayres, J.M., Lima, D.M., Martins, E.S. and Leme, J.L. 1990. On the track of the road: changes in subsistence hunting in a Brazilian Amazonian village. In Wildlife Uses in the Neotropics, (eds J. G. Robinson and K. Redford). Chicago University Press.

Bodmer, R.E., Fang, T.G. and Ibanez, L.M. in press. Primates and ungulates: a comparison in susceptibility to hunting. Primate Conservation.

Castro, N., Revilla, J. and Neville, M. 1976. Carne de monte como una fuente de proteinas en Iquitos, con referencia especial a monos. Rev. Forestal Peru, 6, 19-32.

Defler, T. 1989. Wild and Woolly. Animal Kingdom, September 1989.

Fooden, J. 1963. A revision of the woolly monkeys (genus Lagothrix). J. Mammal. 44, 213-217.

Freese, C.H., Castro, R.N. Heltne, P.G. and Whitesides, G. 1982. Patterns and determinants of monkey densities in Peru and Bolivia, with notes on distributions. Int. J. Primatol. 1, 53-90.

Green, K.M. 1976. The nonhuman primate trade in Colombia. In Neotropical Primates: Field Studies and Conservation (eds R. W. Thorington, Jr. and P. G. Heltne). Nat. Acad. of Sciences, Washington, DC.

Johns, A.D. 1986. Effects of habitat disturbance on rainforest wildlife in Brazilian Amazonia. Unpubl. report to World Wildlife Fund-US, Washington, DC.

Mack, D. and Kafka, H. 1978. Breeding and rearing of woolly monkeys at the National Zoological Park, Washington. Int. Zoo Yb. 18, 117-122.

Medina, J.T. 1934. The Discovery of the Amazon According to the Account of Friar Gaspar de Carvajal and Other Documents. American Geographic Society, New York.

Mittermeier, R.A. 1987. Effects of hunting on rain forest primates. In Primate Conservation in the Tropical Rain Forest, (eds C. Marsh and R. A. Mittermeier). Alan R. Liss, New York.

Peres, C.A. 1990. Effects of hunting on western Amazonian primate communities. Biol. Cons. 54, 47-59.

Rylands, A.B. 1985. Conservation areas protecting primates in Brazilian Amazonia. Primate Conservation, 5, 24-27.

Soini, P. 1972. The capture and commerce of live monkeys in the Amazonian region of Peru. Int. Zoo. Yb. 12, 26-36.

Soini, P. 1986. A synecological study of a primate community in the Pacaya-Samiria National Reserve, Peru. Primate Conservation, 7, 63-71.

Symington, M.M. 1987. Ecological and social correlates of party size in the black spider monkey, Ateles paniscus chamek. Unpubl. Ph.D. Thesis. Princeton University, Princeton.

Thornback, J. and Jenkins, M. 1982. The IUCN Mammal Red Data Book, Part I: Threatened mammalian taxa of the Americas and Australasian zoo-geographic regions (excluding Cetacea). International Union for Conservation of Nature and Natural Resources, Gland.

Williams, L. 1967. Breeding Humboldt's woolly monkey Lagothrix lagotricha at Murrayton Woolly Monkey Sanctuary. Int. Zoo. Yb, 7, 86-89.

Youst, J.A. and Kelley, P.M. 1983. Shotguns, blowguns, and spears: the analysis of technological efficiency. In Adaptive Responses of Native Amazonians (eds R. B. Hames and W. T. Vickers), Academic Press, London.

Carlos Peres, Museu Goeldi/Zoologia, C.P. 399, Belém, Pará, 66.000, Brazil; and Sub-Department Veterinary Anatomy, University of Cambridge, Cambridge CB2 1QS, UK. 